\title{
THE STUDY OF THE INFLUENCE OF CHEMICAL NATURE OF FUNCTIONAL GROUPS IN OLIGOMERIC AND LOW-MOLECULAR MODIFIERS ON THE RHEOLOGICAL PROPERTIES OF THE EPOXY OLIGOMER
}

\author{
Elena Barabash ${ }^{1}$, Yuriy Popov ${ }^{1}$, Yuliya Danchenko ${ }^{1,} \bowtie$
}

https://doi.org/10.23939/chcht15.01.053

\begin{abstract}
The influence of chemical nature of modifier functional groups on the level of intermolecular interactions in the system "epoxy oligomer - modifier", as well as the structure formation and dynamic viscosity of epoxy oligomer has been studied in detail. Modifying additives in low concentrations contribute to an increase in the degree of structure formation of the epoxy system by increasing the intermolecular interaction between the associates of the epoxydiane oligomer. It was established that the strength of the formed coagulation structures depends both on the compatibility parameter of the modifiers and ED-20, and on their intermolecular interaction energy.
\end{abstract}

Keywords: epoxy oligomer, modifying additive, dynamic viscosity, intermolecular interaction, computer modeling, compatibility parameter.

\section{Introduction}

It is known that the increased viscosity of epoxy oligomers is determined by the level of intermolecular interactions between molecules in such polar groups as hydroxyls (the possibility of hydrogen bonds formation), epoxy and simple ethers (dipole-dipole interactions), as well as benzene nuclei ( $\pi$ - $\pi$ interaction) $[1,2]$. Therefore, epoxydian oligomers are highly viscous associated liquids [3]. The viscosity of epoxy oligomer binders determines the timing of their application and distribution on the surface, as well as reinforcing fillers impregnation. The reduction of viscosity ensures high-quality impregnation of fillers with binders and obtaining materials and coatings with a uniform structure, which affects the

\footnotetext{
${ }^{1}$ Kharkiv National University of Civil Engineering and Architecture, 40, Sumska St., Kharkiv, Ukraine

u_danchenko@ukr.net

(C) Barabash E., Popov Y., Danchenko Y., 2021
}

performance properties. In this regard, the regulation of the epoxy binder viscosity is one of the most important stages in the production of epoxy polymeric materials. Moreover, the initial viscosity and the structure of the liquid epoxy oligomer significantly affect the kinetics of the solidification process and the subsequent formation of topological and supramolecular structures in epoxy polymers.

Modifying additives are low viscosity oligomers and plasticizers of various chemical nature containing epoxy, cyclocarbonate, complex ether, and other polar groups. They are widely used to improve the complex of technological properties of epoxy binders [4-6]. Adding polar groups of different nature to the liquid epoxy oligomer under these conditions should lead to a change in the level of intermolecular interaction, structural organization and, ultimately, dynamic viscosity. It was previously established [7-9] that in the epoxy systems studied, the structuring processes are determined by the interactions between the functional groups of oligomers that represent the active centers of Lewis and Bronsted.

Therefore, the purpose of this work is to provide a more detailed study of how the chemical nature of functional groups in modifiers influences the level of intermolecular interactions in the system "epoxy oligomer modifier", as well as the structure formation and dynamic viscosity of epoxy oligomer.

\section{Experimental}

This research studied an epoxy oligomer ED-20 $(M=419 \mathrm{~g} / \mathrm{mol})$. As the modifying additives were used such reactive oligomers as triglycidyl ether of oligooxypropylenetriol Laproxide-503 ( $\mathrm{M}=481 \mathrm{~g} / \mathrm{mol})$, tricyclocarbonate propyl ether of oligooxypropylenetriol Laprolate-803 $(M=854 \mathrm{~g} / \mathrm{mol})$ and dibutylphthalate (DBP) plasticizer $(M=278 \mathrm{~g} / \mathrm{mol})$. The amount of added 
modifying additives were $100 \mathrm{vol} \%$ relative to ED-20 oligomer.

Determination of intermolecular interactions in the epoxy oligomer with modifying additives was carried out by the semi-empirical calculation of PM3 [10] using the HyperChem software package for computer simulation. Three-dimensional models of intermolecular complexes were constructed. The following characteristics such as intermolecular distance, dipole moments, enthalpy of formation $\Delta H_{\text {form }}$ and the energy of interaction $E_{\text {int }}$ of individual compounds and intermolecular complexes were obtained. The interaction energy in ED-20+ modifier complexes $(\mathrm{AB})$ was determined by the difference between the heat of formation in the $\mathrm{AB}$ complex $\left(\Delta H_{\text {form }}\right.$ $\mathrm{AB})$ and the heat of formation in ED-20 (A), $\left(\Delta H_{\text {form }}\right)$ and the modifier $\mathrm{B}\left(\Delta H_{f o r m \mathrm{~B}}\right)$ :

$$
\begin{gathered}
\mathrm{A}+\mathrm{B}=\mathrm{AB} \\
E_{\text {int }}=\Delta H_{\text {form } \mathrm{AB}}-\left(\Delta H_{\text {form } \mathrm{A}}+\Delta H_{\text {form } \mathrm{B}}\right)
\end{gathered}
$$

To obtain data on the degree of intermolecular interactions in the "oligomer-modifier" system and the concentration dependences of the largest and smallest Newtonian viscosities, the viscosity was calculated by the additivity rule and the Bedaux method.

It is known that there is a logarithmic additivity of viscosity in a homogeneous mixture [11]:

$$
\lg \eta_{\text {mixture }}=\varphi_{1} \cdot \lg \eta_{1}+\left(1-\varphi_{1}\right) \cdot \lg \eta_{2}
$$

where $\varphi_{1}, \eta_{1}$ and $\eta_{2}$ are the volume fraction and viscosity of the corresponding components of the polymer matrix, respectively, vol \%.

The calculation of the viscosity of the non-filled biphasic mixtures was carried out by the Bedaux equation [12]:

$$
\eta=\eta_{1}\left\{1+2.5 \times 2 \frac{\eta^{2}-\eta_{1}}{\eta_{2}+1.5 \eta_{1}} \times\left[1-x_{2} \frac{\eta_{2}-\eta_{1}}{\eta_{2}+1.5 \eta_{1}}\right]^{-1}\right\}
$$

where $\eta_{1}$ and $\eta_{2}$ are the viscosity of the continuous and dispersed phases of the mixture, $\mathrm{Pa} \cdot \mathrm{s} ; x_{2}$ is the volume fraction of the dispersed phase, vol $\%$.

Dynamic viscosity of the initial components in compositions is defined experimentally at $293 \mathrm{~K}: 8.5 \mathrm{~Pa} \cdot \mathrm{s}$ for ED-20; 1.4-1.3 Pa.s for Laproxide-503; 2.9-2.1 Pa.s for Laprolate-803 and 0.19 Pa.s for dibutyl phthalate (DBP).
Evaluation of the contribution of each component of the "epoxy oligomer-modifier" mixture to the effectiveness of intermolecular interactions and the structure nature was carried out by the flow curves using Hoppler viscosimeter at the temperature of $293 \mathrm{~K}$ under the shearing stress up to $1800 \mathrm{~Pa}$.

\section{Results and Discussions}

For a preliminary evaluation of the intermolecular interactions in the "oligomer-oligomeric" and "modifiermodifier" systems we calculated three-dimensional solubility parameters in the framework of the general solubility parameter, which can be represented as the sum of the values of three separate parameters [13]:

$$
\begin{gathered}
\delta^{2}=\frac{\left(\Delta E_{d}+\Delta E_{P}+\Delta E_{\mathrm{h}}\right)}{V_{M}}=\delta_{d}^{2}+\delta_{p}^{2}+\delta_{h}^{2}=\delta_{p}^{2}+\delta_{a}^{2} \\
\delta_{a}^{2}=\delta_{p}^{2}+\delta_{h}^{2}
\end{gathered}
$$

where $\Delta E_{d}, \Delta E_{p}$ and $\Delta E_{h}$ are energies that take into account dispersion, polar (dipole-dipole and induction) interactions, as well as interactions in the hydrogen bonds, $\mathrm{kJ} / \mathrm{mol} ; \delta_{d}, \delta_{p}$ and $\delta_{h}$ are the corresponding solubility parameters, $\left(\mathrm{MJ} / \mathrm{m}^{3}\right)^{1 / 2} ; \delta_{a}^{2}$ is an associative solubility parameter, $\left(\mathrm{MJ} / \mathrm{m}^{3}\right)^{1 / 2} ; V_{M}$ is a molar volume, $\mathrm{m}^{3} / \mathrm{mol}$.

Table 1 shows the calculated data based on the solubility parameters of the modifiers and the epoxy oligomer. It is shown that an epoxy oligomer has the greatest value of the three-dimensional parameter $\delta=$ $=21.2\left(\mathrm{MJ} / \mathrm{m}^{3}\right)^{1 / 2}$, and dispersion component makes a bigger contribution, despite the fact that the oligomers have a whole set of polar groups in their structure capable of dipole-dipole and specific interactions.

From the presented data, it follows that among the modifiers studied, the values of the solubility parameters increase from DBP containing a complex etheric polar group, to Laproxide-503 and Laprolate-803 containing 3 epoxy and 3 cyclocarbonate groups, respectively. Moreover, the dipole-dipole $\left(\delta_{p}\right)$ and hydrogen bonds interactions $\left(\delta_{h}\right)$, which determine the size of the associative parameter $\left(\delta_{a}\right)$, contribute to the value of the three-dimensional solubility parameter.

Table 1

Solubility parameters of an epoxy oligomer and modifying additives

\begin{tabular}{|l|c|c|c|c|}
\hline $\begin{array}{c}\text { Oligomer, } \\
\text { modifiers }\end{array}$ & $\begin{array}{c}\text { Dispersion component } \delta_{d}, \\
\left(\mathrm{MJ} / \mathrm{m}^{3}\right)^{1 / 2}\end{array}$ & $\begin{array}{c}\text { Polar component } \delta_{P}, \\
\left(\mathrm{MJ} / \mathrm{m}^{3}\right)^{1 / 2}\end{array}$ & $\begin{array}{c}\text { Hydrogen bonds } \\
\text { interaction, }\left(\mathrm{MJ}^{3} / \mathrm{m}^{3}\right)^{1 / 2}\end{array}$ & $\begin{array}{c}\text { Solubility parameter, } \\
\left(\mathrm{MJ} / \mathrm{m}^{3}\right)^{1 / 2}\end{array}$ \\
\hline ED-20 & 19.79 & 5.06 & 5.21 & 21.1 \\
\hline Laproxide-503 & 17.40 & 7.46 & 7.46 & 20.4 \\
\hline Laprolate-803 & 16.06 & 10.93 & 7.99 & 21.0 \\
\hline $\begin{array}{l}\text { Dibutyl } \\
\text { phthalate }\end{array}$ & 16.28 & 9.06 & 5.57 & 19.2 \\
\hline
\end{tabular}


The presented data show that the values of the solubility parameters of Laprolate-803 and ED-20 are the closest comparing with DBP and Laproxide-503. At the same time, it is known that the parameters $\delta$ characterize only the energy expended on separating the modifier molecules from each other; they reflect the interaction energy only between these molecules and are not always the measure of the interaction energy between the modifier and the epoxy oligomer [14].

The nature of the intermolecular interactions of ED-20 and modifying additives was studied using computer simulation by the method of the semiempirical calculation PM3 in the HyperChem program. As a result of the computer simulation, the next parameters were obtained: the intermolecular distance and dipole moments, the enthalpies of the formation $\Delta H_{\text {form }}$ and the interaction energy $E_{\text {int }}$ of individual compounds and intermolecular complexes, which are presented in Table 2. Threedimensional models of ED-20 molecules interacting are presented in Fig. 1 and models of ED-20 and modifiers molecules interacting are presented in Figs. 2-4. Symbols of atoms in molecular models are presented in Fig. 5.

Fig. 1 shows that the epoxy oligomer molecules are oriented by the epoxy group of one molecule towards the hydroxyl group of another molecule. The distance between the atoms of Oxygen and Hydrogen is 7.5 $\AA$, and the energy of interaction of the molecules ED-20 is $65.58 \mathrm{~kJ} / \mathrm{mol}$. This energy value is typical of the hydrogen bonds interaction and all types of Van der Waals interactions, which usually lead to the association of molecules and to the growth of viscosity. Figs. 2-4 show computer models of molecular complexes between ED-20 molecules and the modifying additive molecule, as well as between two ED-20 molecules and one modifier molecule.

It can be seen from these figures that the molecules of Laprolate-803 and Laproxide-503 with their functional end groups containing proton-receptor oxygen atoms are oriented to the hydroxyl group of ED-20, and the interaction energy is 38.16 and $17.27 \mathrm{~kJ} / \mathrm{mol}$, respectively (Table 2). These quantities are close to the energies of hydrogen bonds. Such a difference in the values of the interaction energies is most likely due to a higher value of the dipole moment of the carbonate group (4.6 D) in the chain of the Laproplate- 803 molecule when compared with the dipole moment of the epoxy group $(1.8 \mathrm{D})$ in the chain of the Laproxide-503.

An aromatic ring in the DBP molecule is oriented toward the epoxy group of a single ED-20 molecule, and a butyl radical in the DBP molecule is oriented toward a hydroxyl group of an ED-20 molecule. The interaction energy of the bimolecular complex ED-20 + DBP is $-8.23 \mathrm{~kJ} / \mathrm{mol}$, and the energy of the interaction of the three-molecular complex ED-20+DBP+ED-20 decreases almost by half and its value is $-3.39 \mathrm{~kJ} / \mathrm{mol}$. Besides, the interaction energy of the three-molecular complex with Laprolate-803 and Lamroxide-503 also decreases, but in this case to the less extent due to three functional and flexible hydroxypropylene units in the structure.

Taking into account the obtained results of calculations of the three-dimensional solubility parameter and computer simulation of the intermolecular interactions degree in the "oligomer-modifier" system, it can be noted that Laprolate-803 is the most compatible with ED-20, while DBP is the least compatible.

Table 2

Computer simulation parameters of molecular complexes

\begin{tabular}{|c|c|c|c|c|}
\hline Molecular complex & $\Delta H_{\text {form }}, \mathrm{kJ} / \mathrm{mol}$ & $E_{\text {int }}, \mathrm{kJ} / \mathrm{mol}$ & $\begin{array}{c}\text { The distance between } \\
\text { the molecules, } \AA\end{array}$ & $\begin{array}{c}\text { Dipole moment } \mu, \\
\mathrm{D}\end{array}$ \\
\hline ED-20 & -473.97 & & & 2.76 \\
\hline ED-20+ ED-20 & -882.35 & 65.6 & 7.5 & 5.51 \\
\hline Laproxide-503 & -1721.3 & & & 5.47 \\
\hline Laproxide-503 + Laproxide-503 & -3443.5 & 0.1 & 9.7 & \\
\hline ED-20 + Laproxide-503 & -2178.0 & 17.27 & 9.5 & 4.59 \\
\hline ED-20 + ED-20 + Laproxide-503 & -2685.23 & -7.19 & & 7.81 \\
\hline Laprolate-803 & -3153.31 & & & \\
\hline Laprolate-803+ Laprolate-803 & -6306.26 & 0.36 & 8.4 & 7.41 \\
\hline ED-20+ Laprolate-803 & -3589.12 & 38.16 & 9.0 & 9.95 \\
\hline ED-20+ ED-20+ Laprolate-803 & -4085.78 & -22.69 & & 2.65 \\
\hline DBP & -892.64 & & & \\
\hline DBP + DBP & -1785.70 & -0.42 & 6.1 & 4.92 \\
\hline ED-20+ DBP & -1374.80 & -8.23 & 7.8 & 7.18 \\
\hline ED-20+ ED-20+ DBP & -1851.36 & -3.39 & & \\
\hline
\end{tabular}




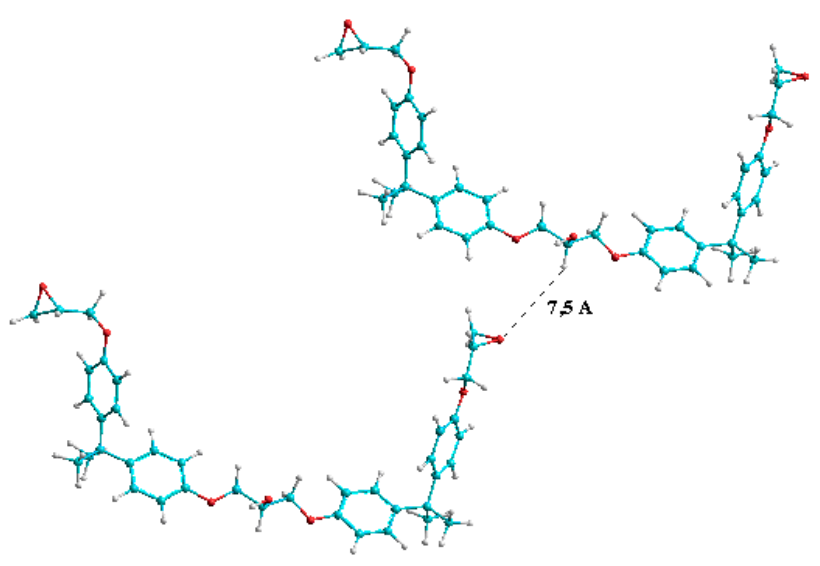

Fig. 1. Geometry of ED-20 molecules
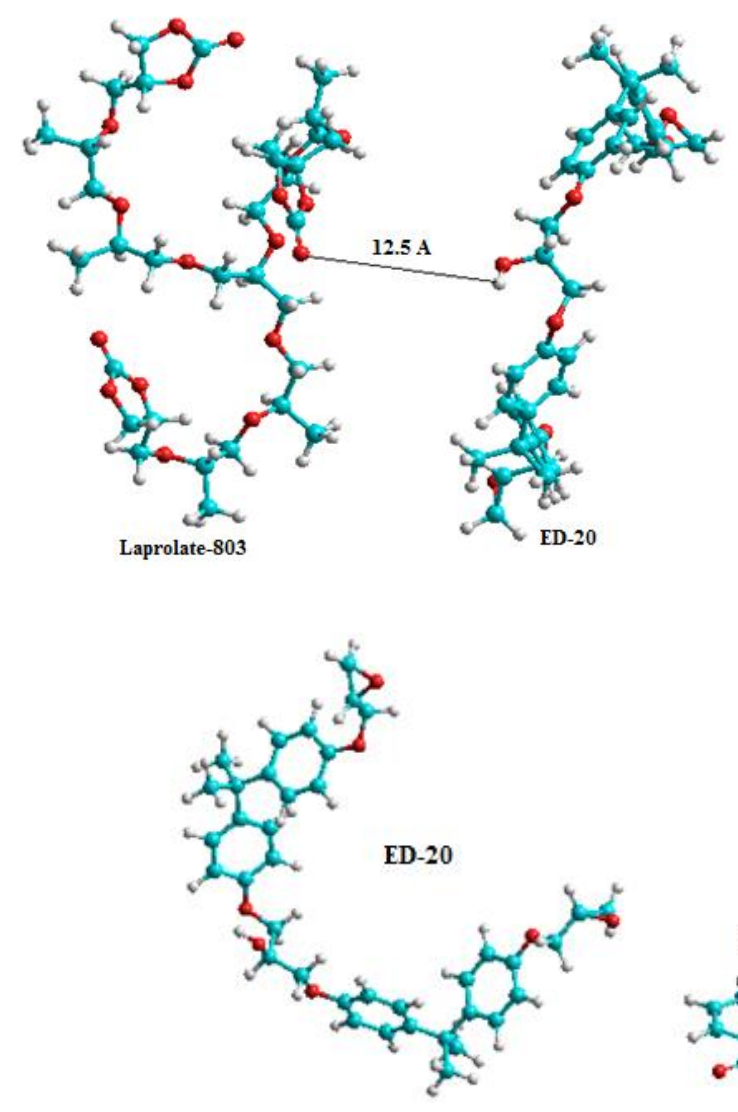

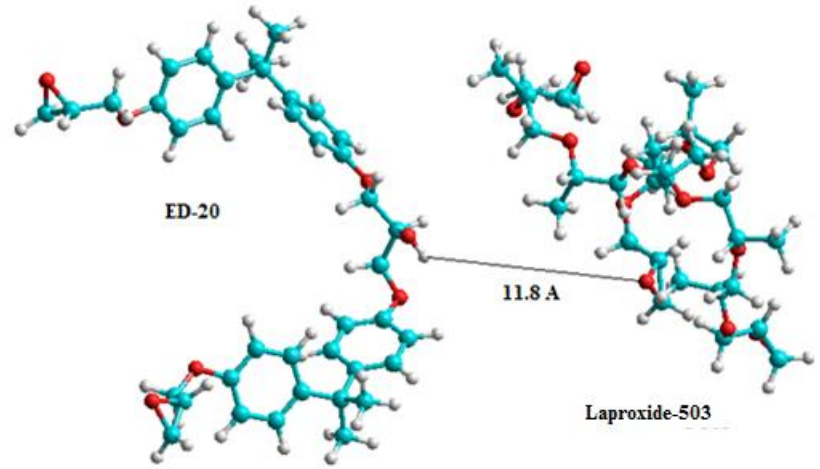

Fig. 2. Geometric optimization of the molecular complex of ED-20 and Laproxide-503

Fig. 3. Geometric optimization of the molecular complex of ED-20 and Lapolate-803

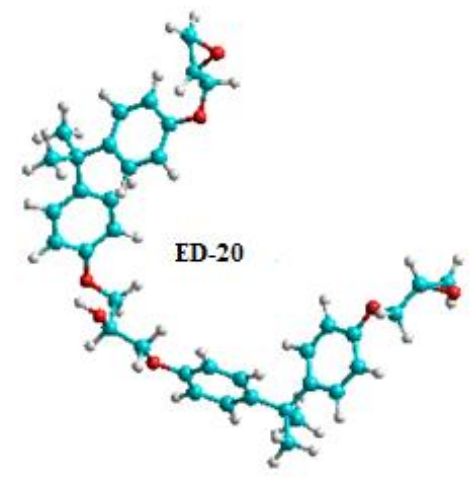

Fig. 4. Geometric optimization of the molecular complex of ED-20 and DBP

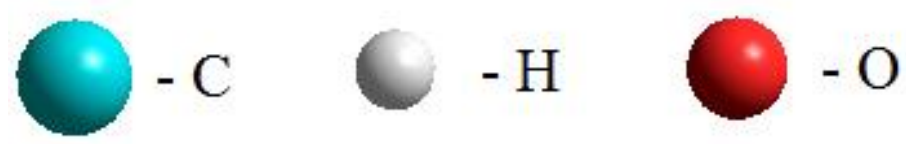

Fig. 5. Atomic conventions 
For the experimental evaluation of the intermolecular interactions degree in the "oligomer-modifier" system, the rheological properties of binary mixtures were studied. The comparison of the concentration dependences of the largest Newtonian viscosities received as experimental and the data calculated by the rule of logarithmic additivity and the Bedaux method were presented.

The experimental results of the dynamic viscosity dependency on shear stresses of the epoxy oligomer ED20 and the modifying additives Laproxide-503 and Laprolate-803, as well as mixtures with ED-20, are shown in Fig. 6.

Rheological curves allowed to determine such structural-rheological characteristics as the maximum viscosity at the initial moment of flow $\left(\eta_{0}\right)$ with the minimally destroyed structure and the viscosity of the "destroyed" structure at the Newtonian flow $\left(\eta_{n}\right)$, anomaly of viscosity $\left(\eta_{0} \eta_{n}\right)$, the flow limit $\left(\tau_{0}\right)$, the shear stress at which the Newtonian flow $\left(\tau_{n}\right)$ begins. The obtained results are presented in Table 3

The data obtained show that the systems studied are structured liquids with the non-Newtonian character of the flow. Obtained values of the viscosity anomaly and the absence of the area with the greatest Newtonian viscosity on flow curves mean that the pure oligomers are liquids with a low degree and can be attributed to pseudoplastics. The modifying oligomers Laproxide-503 and Laprolate-803 are characterized by a significantly lower strength of the structure, compared with the epoxy oligomer, the structural viscosity range of which extends to $2800 \mathrm{~Pa}$ on the flow curve. These data are in good agreement with the previously calculated interaction energy between bimolecular complexes.

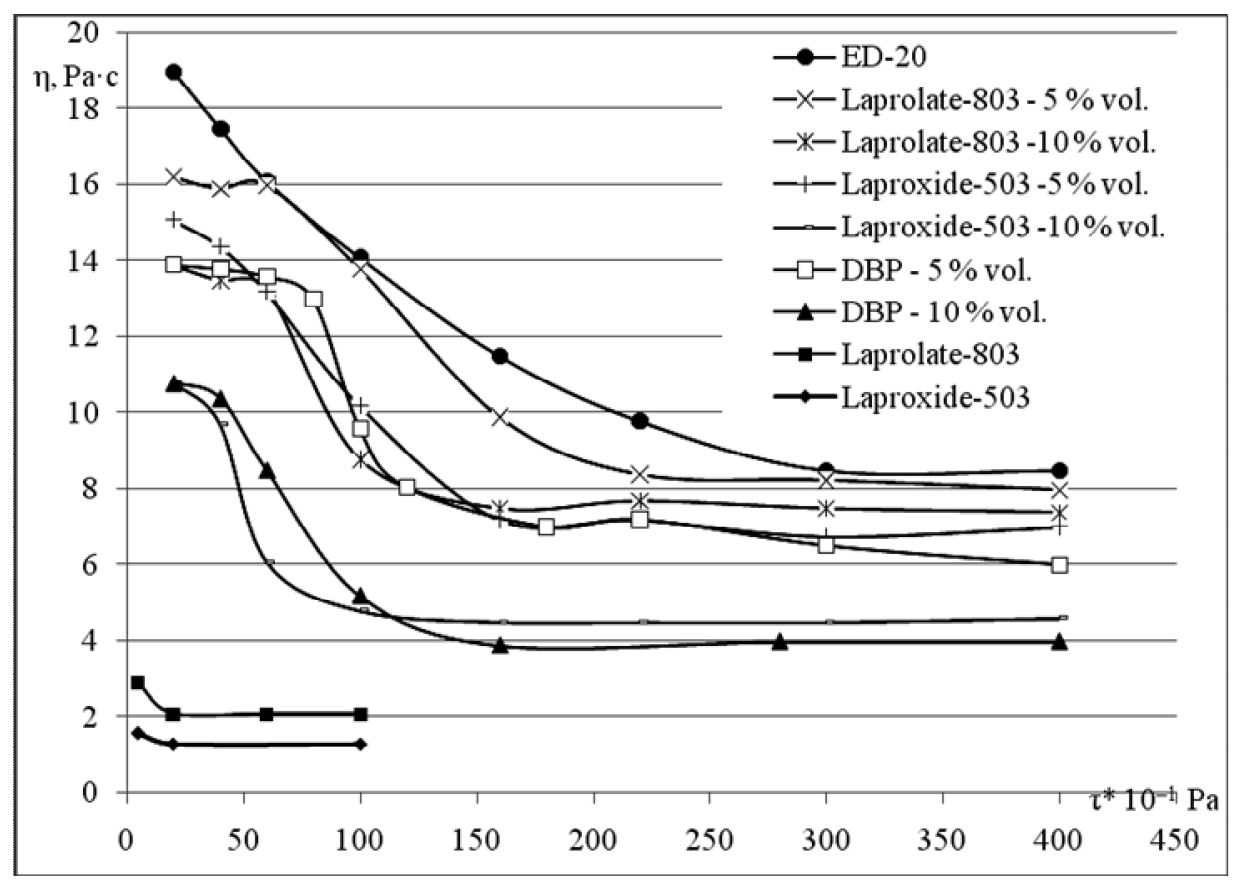

Fig. 6. The flow curves of ED-20 and compositions with modifying additives

Table 3

Structural-rheological characteristics of epoxy compositions

\begin{tabular}{|l|c|c|c|c|c|}
\hline \multicolumn{1}{|c|}{ Composition, vol \% } & $\tau_{0}, \mathrm{~Pa}$ & $\tau_{n}, \mathrm{~Pa}$ & $\eta_{0}, \mathrm{~Pa} \cdot \mathrm{s}$ & $\eta_{n}, \mathrm{~Pa} \cdot \mathrm{s}$ & $\eta_{0} / \eta_{n}$ \\
\hline ED-20 - 100 \% vol & 200 & 2800 & 19.0 & 8.5 & 2.24 \\
\hline ED -20 + Laproxide -503 5\% vol & 350 & 1600 & 15.1 & 6.5 & 2.32 \\
\hline ED -20 + Laproxide -503 10\% vol & 290 & 750 & 10.8 & 4.5 & 2.4 \\
\hline ED -20 + Laprolate -803 5\% vol & 600 & 2000 & 16.0 & 8.2 & 1.95 \\
\hline ED -20 + Laprolate -803 10\% vol & 600 & 1600 & 13.8 & 7.8 & 1.76 \\
\hline ED -20 + DBP 5 \% vol & 800 & 1250 & 14.0 & 7.0 & 2.0 \\
\hline ED -20 + DBP 10 \% vol & 500 & 1200 & 10.5 & 4.0 & 2.63 \\
\hline Laprolate - 803 - 100 \% vol & 20 & 200 & 2.9 & 2.1 & 1.3 \\
\hline Laproxide - 503-100 \% vol & 20 & 100 & 1.4 & 1.3 & 1.1 \\
\hline
\end{tabular}


The obtained results give grounds to assume that the epoxy oligomer is a strongly associative fluid. The decrease of viscosity with the growth of displacement stress at the initial stage can occur due to the weakening of the bonds between the molecule associations. Higher shear stresses can lead to the breakage of bones between associations and to their destruction.

Adding Laproxide-503, Laprolate-803 and DBP to ED-20 does not change the format of the flow curves, but there are areas with the highest Newtonian viscosity in the area with low values of shear stresses. There is a narrowing and displacement of the effective structural viscosity area towards the low values of shear stresses, especially in the presence of Laproxide-503 and DBP. In the case of adding 5 vol \% of Laproplate- 803 and DBP, the degree of viscosity anomaly decreases; in the case of Laproxide-503 it increases (Table 3). It is noteworthy that when adding $10 \mathrm{vol} \%$ of Laproxide-503 to ED-20, an area characterized by the smallest Newtonian flow appears at lower shear stresses $(\sim 1000 \mathrm{~Pa})$ than in the presence of the same amount of DBP $(\sim 1600 \mathrm{~Pa})$ under equal initial viscosities $\left(\eta_{0}\right)$ of both modifiers. This factor may be a priority when we choose modifiers to make the fiber fillers soaking easier.

Fig. 6 also depicts that after adding Laprolate- 803 to ED-20 the flow curve shows the area with the greatest Newtonian viscosity, which indicates the formation of rapidly restoring sufficiently strong spatial structures $\left(\tau_{0}=60-800 \mathrm{~Pa}\right)$. It can be due to strong intermolecular interactions after formation of hydrogen bonds of Laproplate-803 with ED-20. This circumstance, coupled with a relatively small value $\tau_{n}$, is valuable in the selection of modifying additives for the development of epoxy coatings. Despite the fact that Laproxide-503 also forms hydrogen bonds with ED-20, those bonds are not that strong (Table 2) and the spatial structure is weak. Stronger spatial structure is formed in the case of DBP addition, but, probably, in another way. If we proceed from the concept of the associative structure of the epoxy oligomer [3], the low-molecular DBP, being incompatible with ED20 , in a small content predominantly lies in the interstructure space of the oligomer. Thereby, the DBP provides the mobility of structural formation by weak Van-der-Waals interactions. It helps to create sufficiently stable spatial grid under conditions of low shearing stress. The spatial structure is destroyed and the viscosity of the composition decreases sharply when the displacement stress increases to $800 \mathrm{~Pa}$ (Table 3). This is a common feature of the poorly compatible systems.

Figs. 7 and 8 represent the experiment results of the concentration dependences at maximum and minimum Newtonian viscosity for mixtures of ED-20 with modifying additives.

Fig. 7 shows that the concentration dependence of the maximum viscosity of the ED-20+Laproxide-503 ( $5 \mathrm{vol} \%)$ mixture is in the area of the additive curve values. An increase of Laproxide-503 content leads to falls into the region below the additive dependence. This indicates the tendency to reduce the epoxy oligomer molecules association with an increase of the Laproxide-503 content due to the formation of intermolecular complexes.

The viscosity concentration dependences for mixtures of ED-20 with Laprolate-803 clearly fall into the region below the values of additive dependencies, which indicates a decrease of the self-association degree of epoxy oligomer molecules and Laprolate- 803 molecules as a result of the formation of intermolecular complexes ED-20+Laprolate-803.
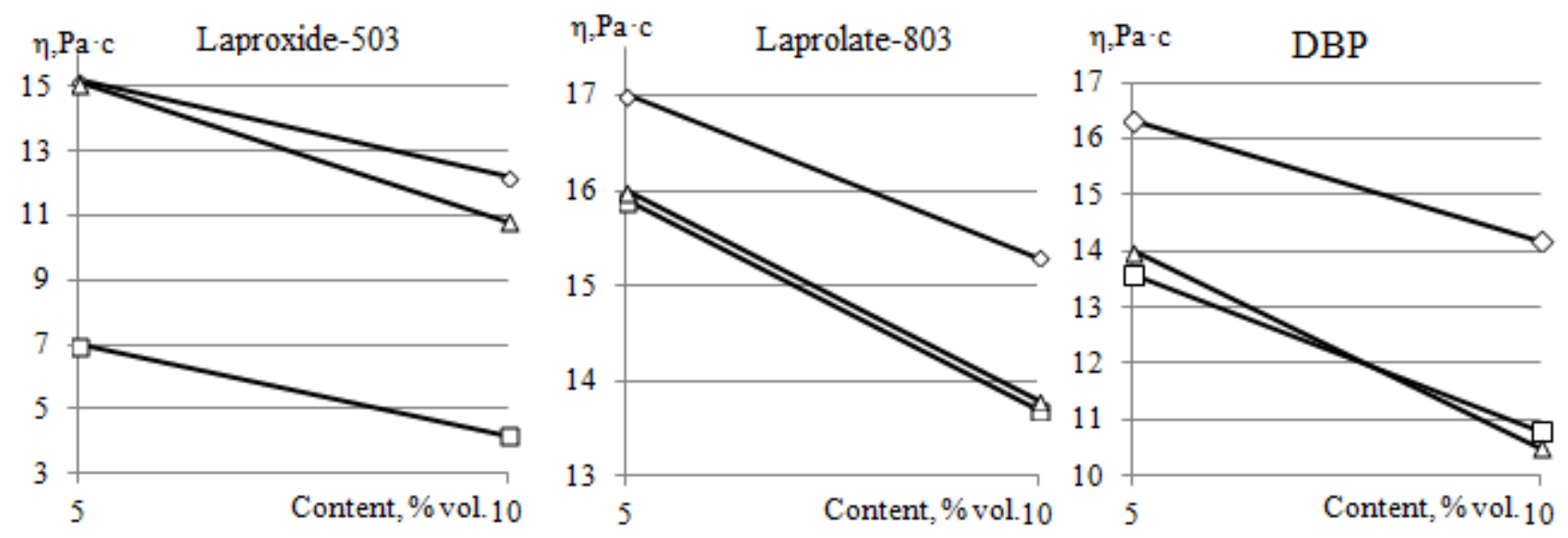

Fig. 7. Maximum viscosity concentration dependences for mixtures ED-20 with modifying additives 

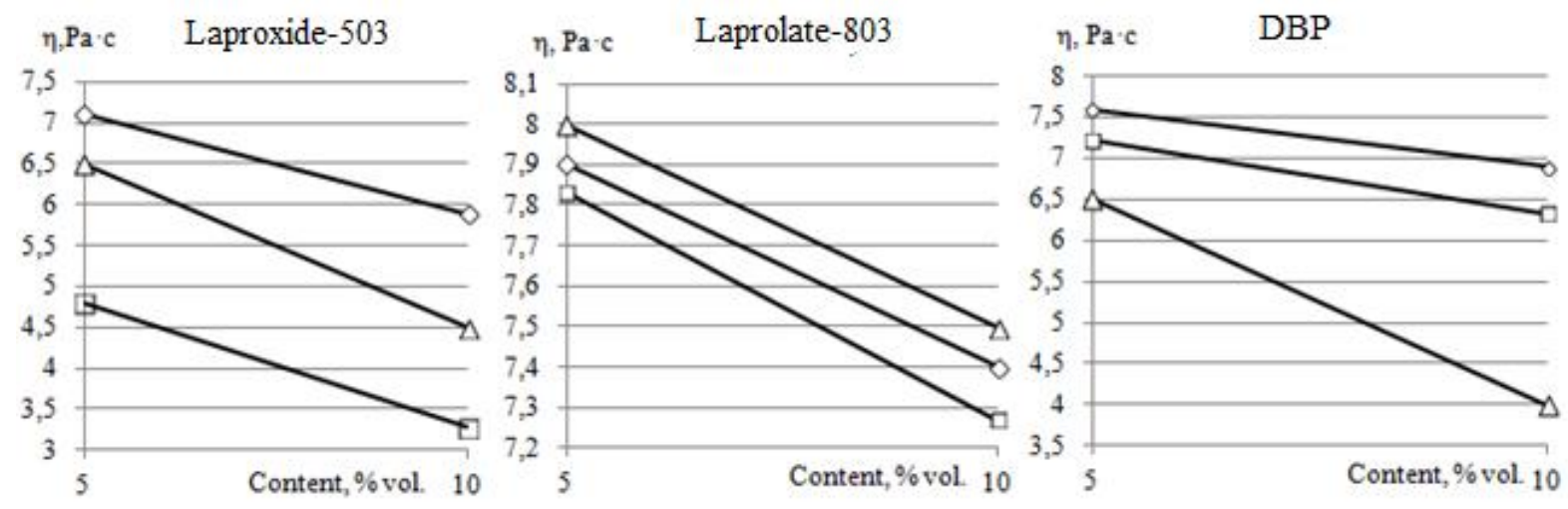

Fig. 8. Newtonian viscosity concentration for mixtures ED-20 with modifying additives

It is also evident that the viscosity concentration dependences for the ED-20+DBP mixture are located in the curve region for two-phase mixtures and with the increase in the DBP content the viscosity concentration dependences go to the region below the values typical for two-phase systems. This may indicate an epoxy oligomer and dibutyl phthalate compatibility deterioration with an increase of DBP concentration.

Rheological properties experiment on the "oligomermodifier" mixture in the area of the minimum Newtonian viscosity (Fig. 8) showed that the viscosity concentration dependence of the ED-20+Laprolate-803 mixture is above the additive dependence. This indicates the specific interactions of the functional groups of the mixture components and the formation of strong intermolecular complexes under strong deformation. Concentration viscosity dependences for ED-20+Laproxide-503 and ED$20+$ DBP mixtures are below the values of additive curves. At the same time, with the increase of the Laproxide-503 content and, especially, DBP by more than $5 \%$, the negative deviation from additive curve also increases. This may indicate a decrease of the intermolecular energy of the epoxy oligomer complexes with DBP and Laproxide-503, as compared to Laroprolate- 803 .

\section{Conclusions}

The solubility parameters of ED-20 and modifying additives were calculated. The nature of intermolecular interactions of ED-20 with modifying additives has been studied by the computer simulation. Experimental studies of dynamic viscosity of ED-20, modifying additives and mixtures were conducted. A comparison of the concentration dependences of the largest and Newtonian viscosities by experimental and calculated data was carried out.

Structural-rheological characteristics and calculated energy of interaction between molecules of epoxy oligomer showed that due to the strong hydrogen bond,
ED-20 is a strongly associate non-Newtonian fluid, with a low degree of structuring. Its relatively high structural strength is caused by the forces of associative intermolecular interaction. The initial area of effective structural viscosity is determined by weak intermolecular bonds between the oligomer associates.

It was shown that the small concentration of studied additives contributes to an increase of the structure formation degree of the epoxy system due to an increase in intermolecular interaction between the epoxy oligomer associations. It was established that the strength of the formed coagulation structures depends on both the solubility parameter of modifiers and ED-20 and their energy of intermolecular interaction.

The decrease of the modified epoxy system structural strength is caused by an increase in the fraction of the formed less stable ED-20+modifier heterocomplexes, in comparison with the strength of the complex ED-20+ED-20. This reduction is even greater, the smaller the energy of the formed complexes ED-20+modifier intermolecular interactions.

The received consistent patterns of oligomer modifiers Laproxide-503 and Laroprolate- 803 influence on the structural-rheological characteristics of the epoxy oligomer can be used for the rational recipes of binders, for use as impregnating compositions or thick-layer coatings.

\section{References}

[1] Surikov P., Trofimov A., Kokhan E. et al.: Int. Polym. Sci. Technol., 2010, 32, 9. https://doi.org/10.1177/0307174X1003701202

[2] Zajcev Ju., Kochergin Ju., Pakter M., Kucher R.: Epoksidnye Oligomery i Kleevye Kompozicii. Naukova Dumka, Kiev 1990.

[3] Augustsson C.: NM Epoxy Handbook, $3^{\text {rd }}$ edn. Nils Malmgren AB, Ytterby 2004.

[4] Khalina M., Beheshty M., Salimi A.: Polym. Bull., 2019, 76, 3905. https://doi.org/10.1007/s00289-018-2577-6

[5] Osipov P., Osipchik V., Smotrova S.: Uspekhi Khimii i

Khimicheskoi Tehnologii, 2008, 22, 53. 
[6] Filipovich A., Ostapjuk S., Bus'ko N. et al.: Polimernyi Zh., 2009, 31, 251.

[7] Danchenko Y., Kachomanova M., Barabash Y.: Chem. Chem. Technol., 2018, 12, 188. https://doi.org/10.23939/chcht12.02.188 [8] Danchenko Y., Andronov V., Barabash E. et al.: East.-Eur. J. Enterpr. Technol., 2017, 6, 4. https://doi.org/10.15587/17294061.2017.118565

[9] Danchenko Yu., Popov Yu., Barabash O.: Voprosy Khimii i Khimicheskoi Tehnologii, 2016, 3, 53.

[10] Wu X., Koslowski A., Thiel W.: Semiempirical Quantum Chemistry [in:] Walker R., Gotz A. (Eds.), Electronic Structure Calculations on Graphics Processing Units: From Quantum Chemistry to Condensed Matter Physics. JohnWiley\&Sons, Ltd 2016. https://doi.org/10.1002/9781118670712.ch11

[11] Ilyin S., Makarova V., Polyakova M. et al.: Mater. Today Commun., 2020, 22. https://doi.org/10.1016/j.mtcomm.2019.100833

[12] Kuleznev V., Kandyrin L.: Vysokomol. Soed. A, 2008, 50, 1180.

[13] Hansen C.: Hansen Solubility Parameters: User's Handbook.

CRC Press, London 2007.

[14] Reichardt C.: Solvents and Solvent Effects in Organic Chemistry, $3^{\text {rd }}$ edn. Wiley-VCH Verlag GmbH, Weinheim 2003.

Received: July 07, 2019 / Revised: August 28, 2019 / Accepted: December 12, 2019

\section{ДОСЛІДЖЕННЯ ВПЛИВУ ХІМІЧНОЇ ПРИРОДИ ФУНКЦОНАЛЬНИХ ГРУП ОЛІГОМЕРНИХ ТА НИЗЬКОМОЛЕКУЛЯРНИХ МОДИФІКАТОРІВ НА РЕОЛОГІЧНІ ВЛАСТИВОСТІ ЕПОКСИДІАНОВОГО ОЛІГОМЕРУ}

Анотація. Вивчено вплив хімічної природи функиіональних груп модифікаторів на рівень міжмолекулярних взаємодій в системі “епоксидний олігомер - модифікатор”, а також на структуроутворення і динамічну в'язкість епоксиолігомеру. Модифікуючі додатки в невеликій концентрації сприяють збільшенню ступеня структуроутворення епоксидної системи внаслідок збільшення міжмолекулярної взаємодії між асоиіатами епоксидіанового олігомеру. Встановлено, щзо міцуність утворених коагуляційних структур залежсть як від параметру сумісності модифікаторів з ЕД-20, так $i$ від їх енергї̈ міжмолекулярної взаємодї.

Ключові слова: епоксиолігомер, модифікуючий додаток, динамічна в'язкість, міжмолекулярна взаємодія, комп'ютерне моделювання, параметр сумісності. 